\title{
The impact of supply chain quality integration on green supply chain management and environmental performance
}

\begin{abstract}
This study develops a model to investigate the relationships between supply chain quality integration (supplier quality integration and customer quality integration), green supply chain management (green purchasing and customer green cooperation), and environmental performance. The model is empirically tested using data collected from 308 manufacturing companies in China. We find that supplier and customer quality integration have positive impact on green purchasing and customer green cooperation, which improve environmental performance. Supplier and customer quality integration also influence environmental performance indirectly through green purchasing and customer green cooperation. The results provide insights into the mechanisms through with supply chain quality integration influences environmental performance and clarify the complex relationships between supply chain quality integration and green supply chain management, contributing to the quality management and green management literature and practices.
\end{abstract}

Keywords: Supplier Quality Integration; Customer Quality Integration; Green Purchasing; Customer Green Cooperation; Environmental Performance

\section{Introduction}

As the world's the largest developing country and a global manufacturing powerhouse, China is facing heavy environmental burden and serious pollution problems (Liu et al., 2009). With the growing environmental awareness of the whole society, the Chinese government has been developing various approaches to protect environment, such as establishing stricter environmental regulations, promoting cleaner production and encouraging ISO 14001 certification (Zhu \& Sarkis, 2004; Li et al., 2016). Chinese manufacturing industries are required to emphasize environmental protection, and green manufacturing has become one of the strategic tasks and priorities in the "Made in China 2025" program and the $13^{\text {th }}$ Five-Year Plan (Zhu, Sarkis \& Lai, 2013). 
Many environmental problems are not caused by the internal operations of a manufacturer, but are related to its upstream and downstream supply chains (Zhu \& Sarkis, 2007; Lai, Wu \& Wong, 2013). Proactive environmental initiatives and programs require supply chain collaboration, and supply chain partners' environmental awareness and capabilities for environmental protection are also critical (Ateş et al., 2012; Blome, Hollos \& Paulraj, 2014; Li et al., 2016). In order to reduce environmental pollution and establish environmental image, manufacturers must actively cooperate with their suppliers and customers to implement green supply chain management (GSCM). GSCM can be defined as "integrating environmental thinking into supply chain management, including product design, material sourcing and selection, manufacturing processes, delivery of the final product to the consumers as well as end-of-life management of the product after its useful life" (Srivastava, 2007:54). Green purchasing and customer green cooperation have been viewed as two key GSCM practices (Zhu \& Sarkis, 2004; Hwang, Wen \& Chen, 2010; Perotti et al., 2012; Green Jr et al., 2012; Yang et al., 2013; Jabbour et al., 2014). More and more Chinese manufacturers are applying green purchasing and customer green cooperation to enhance environmental performance. For example, Sony (China) has actively carried out the "green partner quality certification system" in recent years, and promoted all its suppliers to comply with Sony group's global environmental standards. Since 2002, more than 1000 Chinese manufacturing companies have become Sony's "green partner". The system not only helps these companies to develop international business, but also contributes to the improvement of environmental standards of Sony's supply chains. Another example is Huawei's green partner certification program. It encourages Huawei's suppliers to implement environmental management systems and product lifecycle management to achieve green design and production, enabling Huawei to control the use of various restricted substances from the source.

Environmental issues have been considered to be a natural extension of quality problems because poor product and process quality inevitably lead to environmental problems (Lai, $\mathrm{Wu}$ \& Wong, 2013). In addition, many quality issues are caused by supply chain processes or operations of suppliers and customers. Implementing quality management through supply chain integration, i.e. supply chain quality integration (SCQI), has become an important way to improve the quality of products and processes (Huo, Zhao \& Lai, 2014; Zhang et al., 2017). SCQI can be defined as “the degree to which an organization's internal functions and external supply chain partners strategically and operationally collaborate with each other to jointly manage intra- and inter- organizational quality-related relationships, communications, processes, etc., with the objective to achieve high levels of quality-related performance at low 
costs" (Huo, Zhao \& Lai, 2014:39). Supplier and customer quality integration are two key practices to structure inter-organizational strategies, practices, and procedures into collaborative and synchronized quality-related processes to fulfil its customers' quality requirements (Zhang et al., 2017). The alignment of quality management with suppliers and customers can reduce defects and waste, and hence failing to apply SCQI may hinder the implementation of sustainable production within a manufacturer (Zhu \& Sarkis, 2004; Vachon \& Klassen, 2006; Wiengarten \& Pagell, 2012; Llach et al., 2013; Wu, 2013). Quality management has been viewed as a key tool in pollution prevention. It can facilitate a manufacturer to implement GSCM and hence can be positively associated with environmental performance (Kuei, Madu \& Lin, 2008; Rao \& Holt, 2005). However, the mechanisms through which quality management influences environmental performance is unclear, and few researchers have linked SCQI with GSCM and environmental performance.

The objective of this study is to empirically investigate the relationships among SCQI, GSCM and environmental performance. It aims to address the following with two research questions: (1) How does SCQI affect GSCM? (2) How do SCQI and GSCM jointly influence environmental performance?

\section{Research hypotheses}

\section{Impact of supplier quality integration on GSCM}

Supplier quality integration accommodates core quality competencies derived from cooperative relationships with suppliers, involving suppliers in internal operations such as product development and quality improvement projects, and supplier development (Kuei, Madu \& Lin, 2008; Huo, Zhao \& Lai, 2014). Through the establishment of long-term, stable, and strategic partnerships, a manufacturer and suppliers can keep consistency in decisionmaking and performance objectives, such as environmental strategies and green manufacturing, especially when facing increasing environmental awareness from various stakeholders (Zhu, Sarkis, \& Geng, 2005). Synchronized planning will prompt the manufacturer and suppliers to jointly manage purchasing processes, including material utilization, technological design and workflow (Flynn, Huo \& Zhao, 2010). Frequent information exchange and communications facilitate the manufacturer to provide product and process specifications with detailed environmental requirements to suppliers, and can urge suppliers to improve environmental image, such as applying for ISO 140001 certification (Wiengarten \& Pagell, 2012). Joint problem solving makes the manufacturer and suppliers become more familiar with each other, 
which helps the manufacturer to coordinate purchasing processes (Zhang et al., 2017). Hence, supplier quality integration can promote a manufacturer to collaborate with suppliers to improve green purchasing (Klassen \& Vachon, 2003; Zhu \& Sarkis, 2007).

Supplier quality integration can effectively ensure that suppliers provide environmentfriendly products with high and consistent quality, which can substantially improve the satisfaction of customers, allowing them to be more actively cooperating with the manufacturer in achieving environmental objectives (Carter \& Carter 1998; Huo, Zhao \& Lai, 2014; Zhu, Sarkis, \& Geng, 2005). The manufacturer is also more willing to increase investments in pollution prevention in downstream supply chains, thereby enhancing green cooperation with customers (Vachon \& Klassen, 2007). As a result, supplier quality integration encourages manufacturers to develop detailed and written environmental policy and planning in supply chain management (e.g. recycle content of packaging and solvent emissions), facilitating customer green cooperation (Vachon \& Klassen, 2006; Blome, Hollos \& Paulraj, 2014). Thus, supplier quality integration provides a basis for achieving cooperative solutions to reduce the environmental impact of the material flows with customers (Yang et al., 2010). Therefore, we propose:

H1a : Supplier quality integration is positively related to green purchasing.

$H 1 b:$ Supplier quality integration is positively related to customer green cooperation.

\section{Impact of customer quality integration on GSCM}

Customer quality integration improves quality capabilities by collaborating with customers on product design and quality improvement, and learning from customers (Kuei, Madu \& Lin, 2008; Huo, Zhao \& Lai, 2014). Customer quality integration can help a manufacturer to use less hazardous materials and optimize production processes, facilitating the implementation of green purchasing (Klassen \& Vachon, 2003; Vachon \& Klassen, 2007). Customer integration is beneficial to the collaborative implementation of cleaner production, green packaging and product recycling in upstream supply chains (Vachon \& Klassen, 2006; Zhu \& Sarkis, 2007). For examples, maintaining close contact with customers helps a manufacturer to better understand and satisfy customer requirements on green management and hence the manufacturer can design better green purchasing processes (Flynn, Huo \& Zhao, 2010). Through synchronized planning with customers in production and delivery processes, green purchasing is much more likely to be implemented because it must take into full account of customers' requirements. In addition, in order to better satisfy customers' requirements, a manufacturer will also actively seek the assistance of suppliers, thus promoting the cooperation 
between the manufacturer and suppliers to establish consistent environmental objectives (Yang et al., 2010). The manufacturer will provide design specifications that include environmental requirements for purchased items to suppliers and use eco-labeling (Zhu \& Sarkis, 2007). Suppliers will be selected using environmental criteria, such as ISO14001 certification, and the manufacturer will become more actively to conduct environmental auditing of suppliers' internal operations and evaluate second-tier suppliers' environmental management practices (Blome, Hollos \& Paulraj, 2014). Thus, customer quality integration will improve green purchasing.

When manufacturers and customers achieving seamless quality integration, the green innovation capabilities of both sides will be enhanced (Chiou et al., 2011; Wu, 2013). The manufacturers are more willing to share private knowledge and co-develop green management strategies with customers (Zhu \& Sarkis, 2004; Flynn, Huo \& Zhao, 2010). Involving customers into quality improvement projects also promotes joint problem solving, such as product recycling and the reduction of energy consumption during transportation and distribution processes, which facilitate customer green cooperation (Zhu, Sarkis, \& Geng, 2005; Vachon \& Klassen, 2006). Moreover, customer quality integration motivates manufacturers to increase the investments in pollution control technologies and adopt an "ex post control" environmental management program, improving customer green cooperation (Vachon \& Klassen, 2007; Wu, 2013). Therefore, we propose:

$H 2 a:$ Customer quality integration is positively related to green purchasing.

$H 2 b:$ Customer quality integration is positively related to customer green cooperation.

\section{Impact of GSCM on environmental performance}

By integrating sustainable objectives into procurement activities, green purchasing plays a significant role in the success of manufacturer's environmental strategies (Chiou et al., 2011; Blome, Hollos \& Paulraj, 2014). With the growing environmental awareness, the demands for environment-friendly products are increasing (Klassen \& Vachon, 2003; Chiou et al., 2011). Green purchasing thus can not only enhance the value of products, but also help manufacturers to establish a good environmental image (Zhu \& Sarkis, 2007). Green purchasing also enables a manufacturer to collaborate with suppliers to design upstream supply chain processes and solve environmental problems, thus enhancing environmental performance (Zhu \& Sarkis, 2004).

Customer green cooperation allows a manufacturer to implement environmental improvement projects to reduce pollution in the downstream supply chains (Vachon \& Klassen, 
2006). Customer green cooperation also enables a manufacturer to comply with various environmental regulations in different markets, enhancing operational performance and competitiveness (Yang et al., 2013). By collaborating with customers to align environmental objectives, a manufacturer can incorporate green philosophy in the design of distribution and transportation processes, reducing carbon emission, waste water, solid wastes and the consumption of hazardous materials in downstream supply chains (Zhu \& Sarkis, 2004; Green Jr et al., 2012). Cooperating with customers on eco-design, cleaner production, and green packaging enables the manufacturer to optimize the production and operations to reduce pollution and energy consumption, improving environmental performance (Yang et al., 2013; Youn et al., 2013; Jabbour et al., 2014). Therefore, we propose:

H3a: Green purchasing is positively related to environmental performance.

H3b: Customer green cooperation is positively related to environmental performance.

The conceptual model is presented in Figure 1.

\section{$======$ Insert Figure 1 about here======}

\section{Research methodology}

\section{Sampling}

The unit of analysis of this study is manufacturing companies. All data were collected through mail survey. Representative companies were randomly selected from Zhejiang province using China Telecom Yellow Pages and provincial business directory. Top managers (e.g. general manager, chairman, CEO and senior executives) and middle managers (e.g. operations managers and supply chain managers) were set as the target respondents. We first confirmed whether a company was willing to participate in the survey by telephone. For the companies who were willing to take the survey, we asked potential respondents for contact information, and mailed questionnaire along with a return envelope and cover letter explaining the purpose and potential value of the survey.

With the help of the bureau of commerce and quality supervision, we sent out 450 questionnaires and eventually received 308 valid questionnaires. Hence, the effective response rate is $68.4 \%$. The respondent profile of companies is shown in Table 1. For the informants, $97.4 \%$ of them are from senior management positions and $84.4 \%$ of them had worked in current positions over three years, which indicate that they were suitable informants. The characteristics of respondents is shown in Table 2. 
$=====$ Insert Table 1-2 about here======

\section{Measures}

Based on the relevant literature, a survey instrument was designed to measure supplier quality integration, customer quality integration, green purchasing, customer green cooperation and environmental performance. A multiple item, seven-point Likert-type scale ( 1 = "strongly disagree";7 = "strongly agree") was employed for all constructs. The constructs and related measurement items are shown in Appendix A.

Supplier quality integration was operationalized as cooperative supplier relationships, supplier communications, supplier involvement in product design and quality process improvement, and supplier certification using nine items (Huo, Zhao \& Lai, 2014; Flynn, Huo $\&$ Zhao, 2010). Customer quality integration was operationalized as cooperative customer relationships, customer communications, customer involvement in product design and quality process improvement, and customer certification using ten items (Huo, Zhao \& Lai, 2014; Flynn, Huo \& Zhao, 2010). Green purchasing was operationalized as incorporating environmental criteria in supplier selection and management using seven items (Zhu \& Sarkis, 2004; Green Jr et al., 2012). Customer green cooperation was operationalized as cooperating with customers for environmental practices, such as eco-design, cleaner production, green packaging, transportation and product take back, using seven items (Zhu \& Sarkis, 2004; Zhu, Sarkis \& Lai, 2013). Environmental performance was measured by five items about carbon emission, waste water, solid wastes, hazardous materials and environmental accidents (Zhu \& Sarkis, 2004).

\section{Non-response bias and common method bias}

According to Armstrong \& Overton (1977), we tested the non-response bias using the T test with the later 108 samples and the earlier 200 samples. The results show that there is no significant difference in supplier quality integration, customer quality integration, green purchasing, customer green cooperation and environmental performance variables. Thus, nonresponse bias is not a problem in this study.

Harmon's single-factor test was used to evaluate common method bias (Podsakoff \& Organ, 1986). The results show that there are five factors with eigenvalue above 1, and the cumulative variance explained is $75.608 \%$ (Table 3 ), in which the largest factor only explains $19.831 \%$ of the total variance. These indicate that common method bias is not a serious problem in this study. 


\section{Unidimensionality, reliability and validity}

Five factors with eigenvalue above 1 are extracted using exploratory factor analysis with maximum variance rotation. Table 3 shows that all factor loadings are above 0.60, explaining $75.608 \%$ of the total variance. Thus, unidimensionality is ensured in this study.

$======$ Insert Table 3 about here======

Table 4 shows that the values of Cronbach's alpha (0.920 0.962) and composite reliability (0.921 0.962) of the constructs are all greater than 0.70, suggesting that all constructs are reliable (Fornell \& Larcker, 1981).

Confirmatory factor analysis was used to evaluate convergent validity. The fit indices of the measurement model are Chi-Square $(655)=897.26$, Comparative Fit Index $(\mathrm{CFI})=0.994$, Non-normed Fit Index $(\mathrm{NNFI})=0.993$, Root Mean Square Error of Approximation $($ RMSEA $)=0.035$ and Standardized Root Mean Square Residual $($ SRMR $)=0.034$, which are all higher than cut-off values suggested by $\mathrm{Hu} \&$ Bentler (1999), indicating that the model can be accepted. Table 4 shows that all factor loadings are higher than $0.70(0.807 \sim 0.882)$ and all $\mathrm{T}$ values are greater than 2.0. In addition, the average variance extracted (AVE) are all greater than $0.50(0.695 \sim 0.724)$ (Table 4), indicating that the scales have good convergent validity (Fornell \& Larcker, 1981). Table 5 shows that the square root of AVE for each factor is higher than the correlation coefficient with other factors, indicating that discriminant validity is achieved (Fornell \& Larcker, 1981).

\footnotetext{
$======$ Insert Table $4-5$ about here======
}

\section{Analyses and results}

In this study, we used structural equation modelling with LISREL 8.70 to test the hypotheses. The fit indices of the structural model are Chi-Square (658) $=925.02(\mathrm{P}<0.001), \mathrm{CFI}=0.993$, NNFI=0.992, RMSEA=0.036 and SRMR=0.059, which are all higher than the cut-off values suggested by $\mathrm{Hu} \&$ Bentler (1999), indicating that the proposed model is well fitted. The standardized path coefficients of the structural model are shown in Figure 2. The model explains $26.3 \%$ of the variance in the environmental performance, and $23.6 \%$ and $27.7 \%$ of the variance in the green purchasing and customer green cooperation respectively.

The results indicate that supplier quality integration is significantly related to green purchasing $(\beta=0.380, \mathrm{p}<0.01)$ and customer green cooperation $(\beta=0.378, \mathrm{p}<0.01)$, suggesting the support for H1a and H1b. The significant path coefficients from customer quality 
integration to green purchasing $(\beta=0.161, \mathrm{p}<0.05)$ and customer green cooperation $(\beta=0.216$, $\mathrm{p}<0.01)$ suggest the support for $\mathrm{H} 2 \mathrm{a}$ and $\mathrm{H} 2 \mathrm{~b}$. Green purchasing $(\beta=0.344, \mathrm{p}<0.01)$ and customer green cooperation $(\beta=0.303, p<0.01)$ are also positively associated with environmental performance, supporting $\mathrm{H} 3 \mathrm{a}$ and $\mathrm{H} 3 \mathrm{~b}$.

We further tested a comparative model in which the direct paths from supplier and customer quality integration to environmental performance were added. The fit indices of the comparative model are Chi-Square $(656)=924.75(\mathrm{P}<0.001), \mathrm{CFI}=0.993, \mathrm{NNFI}=0.992$, RMSEA $=0.037$ and SRMR=0.059, and the ratio of Chi-Square/df is 1.410 , which is slightly higher than the proposed model (Chi-Square/df =1.406). The results show that the direct effects of supplier and customer quality integration on environmental performance are not significant. In addition, the path coefficients from supplier and customer quality integration to green purchasing and customer green cooperation and those from green purchasing and customer green cooperation to environmental performance are similar compared with the original model. Hence, the proposed model is robust and better compared with the comparative model due to principle of parsimony.

$======$ Insert Figure 2 about here======

\section{Discussion and conclusions}

This study empirically examines the impact of supplier and customer quality integration on green purchasing, customer green cooperation and environmental performance. We find that supplier and customer quality integration are all beneficial to the implementation of green purchasing and customer green cooperation, which improve environmental performance. These findings contribute to both the theories and practices of quality management and green management in supply chains.

\section{Theoretical contributions}

\section{SCQI and GSCM}

We find that SCQI enhances GSCM directly. The finding is consistent with current arguments that quality management can promote environmental management (Wiengarten \& Pagell, 2012; Llach et al., 2013) and the adoption of green purchasing and customer green cooperation (Jabbour et al., 2014). Quality and environmental management have become two closely related business practices for a long time, and green has become an important aspect of product 
and process quality. This study further reveals that SCQI facilitates the implementation of green management in supply chains, contributing to literature by providing empirical evidence that SCQI is an important antecedent of GSCM (Zhu \& Sarkis, 2004).

The results reveal that supplier quality integration improves both green purchasing and customer green cooperation, which is consistent with existing empirical evidence (Rao \& Holt, 2005; Vachon \& Klassen 2006; Vachon \& Klassen, 2007; Wu, 2013). Maintaining close communications with suppliers on quality considerations and design changes can help companies to choose qualified suppliers through environmental audits, which leads to the purchasing of environmental-friendly materials. In addition, maintaining cooperation with suppliers in terms of quality management can help companies to better meet customer requirements, so that customers will be more willing to cooperate with the company on environmental management.

We also find customer quality integration promotes the implementation of green purchasing and customer green cooperation, which extends the findings of Vachon \& Klassen (2006), Vachon \& Klassen (2007) and $\mathrm{Wu}$ (2013). Customer involvement in quality improvement process can help a manufacturer to implement environmental design, green packaging, product recycling and other green practices, thus reducing energy consumption and environmental impact during the whole life cycle of products. In addition, customer involvement in quality management also requires the greening of a manufacturer's internal operations, which promotes the manufacturer to seek assistance from suppliers in order to meet customer requirements, thus facilitating the implementation of green purchasing.

\section{GSCM and environmental performance}

The study provides empirical evidence that both green purchasing and customer green cooperation can help manufacturers to obtain better environmental performance, which is consistent with existing findings (Carter \& Carter, 1998; Rao \& Holt, 2005; Zhu, Sarkis \& Geng, 2005; Zhu, Sarkis \& Lai, 2013). Green purchasing can lead to the greening of inputs, which can fundamentally reduce the subsequent negative effects caused by raw materials and components throughout the life cycle of products, and hence a company can apply green manufacturing. Manufacturers' green initiatives require the cooperation of customers and there is no exception for GSCM practices, such as eco-design, cleaner production, green packaging, energy saving and product recovery. With more and more stricter government regulations and increasing pressures from various stakeholders, customer green cooperation will inevitably help manufacturers to improve operations to develop green outputs, which leads to better 
environmental performance.

\section{SCQI and environmental performance}

Bootstrapping and Sobel test were applied to further investigate the indirect effects of SCQI on environmental performance and the results are presented in table 6 and 7 respectively. We find that supplier and customer quality integration enhance environmental performance indirectly by improving green purchasing and customer green cooperation. The findings clarify the mechanisms through which SCQI influences environmental performance (Kuei, Madu \& Lin, 2008; Hwang, Wen \& Chen, 2010; Llach et al., 2013; Jabbour et al., 2014). The results enrich current understandings on the performance consequences of SCQI (Huo, Zhao \& Lai, 2014; Zhang et al., 2017). Hence, this study reveals that GSCM plays an important role in connecting SCQI with environmental performance. Therefore, implementing SCQI can essentially not only improve manufacturing processes and product quality, but also reduce various environmental pollutants and bring environmental benefits. A manufacturer must apply GSCM at the same time to fully reap SCQI's benefits on environmental performance.

$======$ Insert Table 6-7 about here======

\section{Practical implications}

The findings also provide guidelines for managers on how to improve environmental performance through integrating quality, environmental, and supply chain management. The implementation of supplier and customer quality integration helps a manufacturer to carry out green purchasing and customer green cooperation. Hence, managers should understand that quality management efforts can lead to the implementation of green practices and there are synergic effects between quality and environment efforts. The findings thus shed lights on how to meet the dual objectives of quality and green. In particular, we suggest manufacturers integrate quality management with suppliers. For example, a manufacturer should maintain cooperative relationships in quality management with suppliers and maintain close communications with suppliers about quality considerations and design changes. A manufacturer should also share quality requirements with suppliers and actively engage suppliers in quality improvement efforts. Resources should be invested to help suppliers to improve their product and process quality. In addition, a manufacturer should frequently in close contact with customers in quality management and involve customers in quality management projects. A manufacturer should also work closely with customers to jointly solve problems. A long-term and collaborative relationship should be built with customers to motive 
customers to provide feedback on quality and delivery performance and inputs into quality control, and to explain quality requirements in details. Moreover, we suggest a manufacturer implement green purchasing and customer green cooperation at the same time to take full advantage of SCQI on environmental performance. For example, we suggest a manufacturer provide design specification to suppliers, co-develop environmental objectives with suppliers, and incorporate environmental criteria in supplier selection and auditing. We also suggest a manufacturer cooperate with customers to develop environmental objectives and apply ecodesign, cleaner production, green packaging and product recall together with customers.

\section{Limitations and future research directions}

This study has three main limitations. First, data used in this study is collected from manufacturing companies in China. Future studies could replicate this study in other countries with different business, institutional and culture environments to generalize the findings. Second, this study measures SCQI, GSCM and environmental performance using perceptual measures. Future studies could empirically explore the relationships among quality management, green management and environmental performance using objective measures. Third, this study focuses on the main effects of SCQI on GSCM and environmental performance. Future studies could investigate the moderating effects of the internal and external contextual factors, such as business and institutional environments and strategic orientation.

\section{References}

Armstrong, J.S., and Overton, T.S. (1977). Estimating nonresponse bias in mail surveys. Journal of Marketing Research, 14(3), 396-402.

Ateş, M.A., Bloemhof, J., van Raaij, E.M., and Wynstra, F. (2012). Proactive environmental strategy in a supply chain context: the mediating role of investments. International Journal of Production Research, 50(4), 1079-1095.

Blome, C., Hollos, D., and Paulraj, A. (2014). Green procurement and green supplier development: antecedents and effects on supplier performance. International Journal of Production Research, 52(1), 32-49.

Carter, C.R., and Carter, J.R. (1998). Interorganizational determinants of environmental purchasing: initial evidence from the consumer products industries. Decision Sciences, 29(3), 659-684. 
Chiou, T., Chan, H.K., Lettice, F., and Chung, S.H. (2011). The influence of greening the suppliers and green innovation on environmental performance and competitive advantage in taiwan. Transportation Research Part E: Logistics and Transportation Review, 47(6), $822-836$.

Flynn, B.B., Huo, B., and Zhao, X. (2010). The impact of supply chain integration on performance: a contingency and configuration approach. Journal of Operations Management, 28(1), 58-71.

Fornell, C., and Larcker, D.F. (1981). Evaluating structural equation models with unobservable variables and measurement error. Journal of Marketing Research, 18(1), 39-50.

Green Jr, K.W., Zelbst, P.J., Meacham, J., and Bhadauria, V.S. (2012). Green supply chain management practices: impact on performance. Supply Chain Management: An International Journal, 17(3), 290-305.

Hu, L.T., and Bentler, P.M. (1999). Cutoff criteria for fit indexes in covariance structure analysis: conventional criteria versus new alternatives. Structural Equation Modeling: A Multidisciplinary Journal, 6(1), 1-55.

Huo, B., Zhao, X., and Lai, F. (2014). Supply chain quality integration: antecedents and consequences. IEEE Transactions On Engineering Management, 61(1), 38-51.

Hwang, Y., Wen, Y., and Chen, M. (2010). A study on the relationship between the PDSA cycle of green purchasing and the performance of the SCOR model. Total Quality Management \& Business Excellence, 21(12), 1261-1278.

Jabbour, A.B.L.D., Jabbour, C.J.C., Latan, H., Teixeira, A.A., and de Oliveira, J.H.C. (2014). Quality management, environmental management maturity, green supply chain practices and green performance of Brazilian companies with ISO 14001 certification: direct and indirect effects. Transportation Research Part E: Logistics and Transportation Review, 67(39-51.

Klassen, R.D., and Vachon, S. (2003). Collaboration and evaluation in the supply chain: the impact on plant-level environmental investment. Production and Operations Management, 12(3), 336-352.

Kuei, C., Madu, C.N., and Lin, C. (2008). Implementing supply chain quality management. Total Quality Management \& Business Excellence, 19(11), 1127-1141. 
Lai, K., Wu, S.J., and Wong, C.W.Y. (2013). Did reverse logistics practices hit the triple bottom line of Chinese manufacturers? International Journal of Production Economics, 146(1), 106-117.

Li, S., Jayaraman, V., Paulraj, A., and Shang, K. (2016). Proactive environmental strategies and performance: role of green supply chain processes and green product design in the Chinese high-tech industry. International Journal of Production Research, 54(7), 21362151.

Liu, Q., Li, H., Zuo, X., Zhang, F., and Wang, L. (2009). A survey and analysis on public awareness and performance for promoting circular economy in China: a case study from Tianjin. Journal of Cleaner Production, 17(2), 265-270.

Llach, J., Perramon, J., Alonso-Almeida, M.D.M., and Bagur-Femenías, L. (2013). Joint impact of quality and environmental practices on firm performance in small service businesses: an empirical study of restaurants. Journal of Cleaner Production, 44,96-104.

Perotti, S., Zorzini, M., Cagno, E., and Micheli, G.J. (2012). Green supply chain practices and company performance: the case of 3PLs in Italy. International Journal of Physical Distribution \& Logistics Management, 42(7), 640-672.

Podsakoff, P.M., and Organ, D.W. (1986). Self-reports in organizational research: problems and prospects. Journal of Management, 12(4), 531-544.

Rao, P., and Holt, D. (2005). Do green supply chains lead to competitiveness and economic performance? International Journal of Operations \& Production Management, 25(9), 898-916.

Srivastava, S.K. (2007). Green supply-chain management: a state-of-the-art literature review. International Journal of Management Reviews, 9(1), 53-80.

Vachon, S., and Klassen, R.D. (2006). Extending green practices across the supply chain: the impact of upstream and downstream integration. International Journal of Operations \& Production Management, 26(7), 795-821.

Vachon, S., and Klassen, R.D. (2007). Supply chain management and environmental technologies: the role of integration. International Journal of Production Research, 45(2), 401-423.

Wiengarten, F., and Pagell, M. (2012). The importance of quality management for the success 
of environmental management initiatives. International Journal of Production Economics, 140(1), 407-415.

Wu, G. (2013). The influence of green supply chain integration and environmental uncertainty on green innovation in Taiwan's IT industry. Supply Chain Management: An International Journal, 18(5), 539-552.

Yang, C., Lin, S., Chan, Y., and Sheu, C. (2010). Mediated effect of environmental management on manufacturing competitiveness: an empirical study. International Journal of Production Economics, 123(1), 210-220.

Yang, C., Lu, C., Haider, J.J., and Marlow, P.B. (2013). The effect of green supply chain management on green performance and firm competitiveness in the context of container shipping in Taiwan. Transportation Research Part E: Logistics and Transportation Review, 55(1), 55-73.

Youn, S., Yang, M.G.M., Hong, P., and Park, K. (2013). Strategic supply chain partnership, environmental supply chain management practices, and performance outcomes: an empirical study of Korean firms. Journal of Cleaner Production, 56, 121-130.

Zhang, M., Guo, H., Huo, B., Zhao, X., and Huang, J. (2017). Linking supply chain quality integration with mass customization and product modularity, International Journal of Production Economics, DOI: 10.1016/j.ijpe.2017.01.011.

Zhu, Q., Sarkis, J., and Geng, Y. (2005). Green supply chain management in China: pressures, practices and performance. International Journal of Operations \& Production Management, 25(5), 449-468.

Zhu, Q., Sarkis, J., and Lai, K. (2013). Institutional-based antecedents and performance outcomes of internal and external green supply chain management practices. Journal of Purchasing and Supply Management, 19(2), 106-117.

Zhu, Q., and Sarkis, J. (2004). Relationships between operational practices and performance among early adopters of green supply chain management practices in Chinese manufacturing enterprises. Journal of Operations Management, 22(3), 265-289.

Zhu, Q., and Sarkis, J. (2007). The moderating effects of institutional pressures on emergent green supply chain practices and performance. International Journal of Production Research, 45(18-19), 4333-4355. 


\section{Appendix A Measures}

\begin{tabular}{|c|c|c|c|}
\hline Construct & No & Item & Sources \\
\hline \multirow{9}{*}{$\begin{array}{c}\text { Supplier } \\
\text { quality } \\
\text { integration }\end{array}$} & SQI01 & $\begin{array}{l}\text { We maintain cooperative relationships in quality management } \\
\text { with our suppliers. }\end{array}$ & \multirow{9}{*}{$\begin{array}{l}\text { Adapted } \\
\text { from Huo, } \\
\text { Zhao \& Lai } \\
\text { (2014) and } \\
\text { Flynn, Huo } \\
\& \quad \text { Zhao } \\
(2010)\end{array}$} \\
\hline & SQI02 & We help our suppliers to improve their quality. & \\
\hline & SQI03 & $\begin{array}{l}\text { We maintain close communications with suppliers about } \\
\text { quality considerations and design changes. }\end{array}$ & \\
\hline & SQI04 & $\begin{array}{l}\text { Our suppliers provide input into quality control in our product } \\
\text { development projects. }\end{array}$ & \\
\hline & SQI05 & $\begin{array}{l}\text { Our suppliers are actively involved in quality management } \\
\text { during our new product development process. }\end{array}$ & \\
\hline & SQI06 & We mostly use suppliers that we have certified. & \\
\hline & SQI07 & $\begin{array}{l}\text { We actively engage suppliers in our quality improvement } \\
\text { efforts. }\end{array}$ & \\
\hline & SQI08 & $\begin{array}{l}\text { We help suppliers to improve their processes to better meet our } \\
\text { quality requirements. }\end{array}$ & \\
\hline & SQI09 & We share quality requirements with our suppliers. & \\
\hline \multirow{10}{*}{$\begin{array}{c}\text { Customer } \\
\text { quality } \\
\text { integration }\end{array}$} & CQI01 & $\begin{array}{l}\text { We are frequently in close contact with our customers in quality } \\
\text { management. }\end{array}$ & \multirow{10}{*}{$\begin{array}{l}\text { Adapted } \\
\text { from Huo, } \\
\text { Zhao \& Lai } \\
(2014) \text { and } \\
\text { Flynn, Huo } \\
\& \quad \text { Zhao } \\
(2010)\end{array}$} \\
\hline & CQI02 & $\begin{array}{l}\text { Our customers give us feedback on our quality and delivery } \\
\text { performance. }\end{array}$ & \\
\hline & CQI03 & $\begin{array}{l}\text { Our customers provide input into quality control during our } \\
\text { product design process. }\end{array}$ & \\
\hline & CQI04 & Our processes are certified, or qualified, by our customers. & \\
\hline & CQI05 & $\begin{array}{l}\text { Our customers are involved in quality management during our } \\
\text { new product development process. }\end{array}$ & \\
\hline & CQI06 & Our customers involve us in their quality improvement efforts. & \\
\hline & CQI07 & Our customers share quality requirements forecast with us. & \\
\hline & CQI08 & We engage customers in our quality improvement efforts. & \\
\hline & CQI09 & $\begin{array}{l}\text { We formulate uniform quality standards in consultation with our } \\
\text { customers. }\end{array}$ & \\
\hline & CQI10 & We jointly solve quality problems with our customers. & \\
\hline \multirow{7}{*}{$\begin{array}{c}\text { Green } \\
\text { purchasing }\end{array}$} & GP01 & $\begin{array}{l}\text { Providing design specification to suppliers that include } \\
\text { environmental requirements for purchased items. }\end{array}$ & \multirow{7}{*}{$\begin{array}{l}\text { Adapted } \\
\text { from Zhu \& } \\
\text { Sarkis } \\
\text { (2004) and } \\
\text { Green Jr et } \\
\text { al. (2012) }\end{array}$} \\
\hline & GP02 & Cooperation with suppliers for environmental objectives. & \\
\hline & GP03 & Environmental audit for suppliers' internal management. & \\
\hline & GP04 & Suppliers' ISO14001 certification. & \\
\hline & GP05 & $\begin{array}{l}\text { Second-tier supplier environmentally friendly practice } \\
\text { evaluation. }\end{array}$ & \\
\hline & GP06 & Suppliers are selected using environmental criteria. & \\
\hline & GP07 & Eco labeling of products. & \\
\hline $\begin{array}{l}\text { Customer } \\
\text { green }\end{array}$ & CGC01 & $\begin{array}{l}\text { Providing design specification which conform to environmental } \\
\text { requirements to customers. }\end{array}$ & $\begin{array}{l}\text { Adapted } \\
\text { from Zhu \& }\end{array}$ \\
\hline cooperation & CGC02 & Cooperation with customers for environmental objectives. & Sarkis \\
\hline
\end{tabular}




\begin{tabular}{ccll}
\hline Construct & No & \multicolumn{1}{c}{ Item } & Sources \\
\hline & CGC03 & Cooperation with customers for eco-design. & (2004) and \\
& CGC04 & Cooperation with customers for cleaner production. & Zhu, Sarkis \\
& CGC05 & Cooperation with customers for green packaging. & \& Lai \\
& CGC06 & $\begin{array}{l}\text { Cooperation with customers for using less energy during } \\
\text { product transportation. }\end{array}$ & (2013) \\
& CGC07 & Cooperation with customers for product take back. & \\
\hline \multirow{2}{*}{ Environmental } & EP01 & Reduction of carbon emission. & Zhu \& \\
performance & EP03 & Reduction of waste water. & Sarkis \\
& EP04 & Decrease in consumption of hazardous materials. & (2004) \\
& EP05 & Decrease in frequency of environmental accidents. & \\
\hline
\end{tabular}




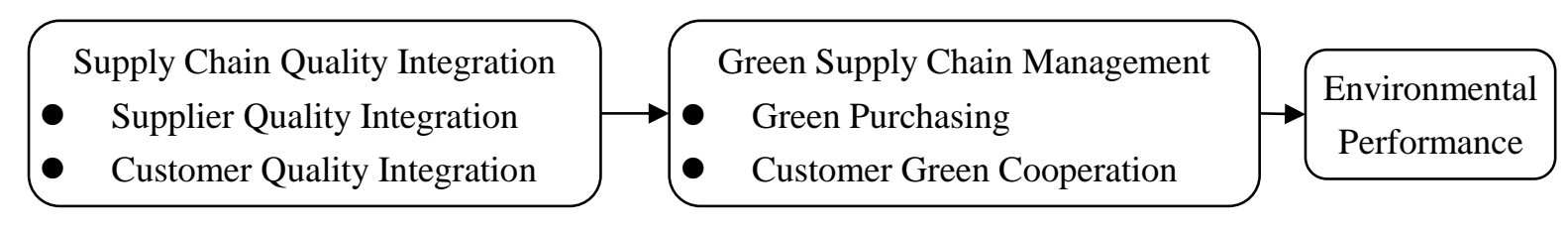

Figure 1. Conceptual model

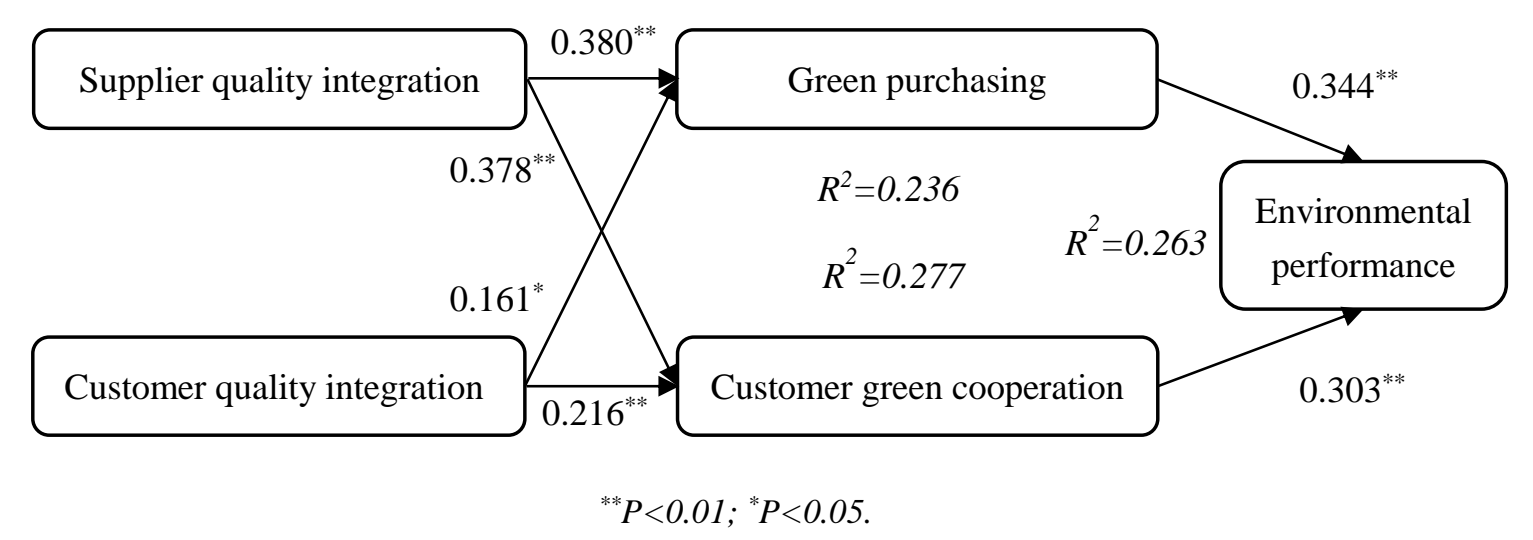

Figure 2. SEM results of the proposed model 
Table 1. Profiles of responding companies

\begin{tabular}{|c|c|c|}
\hline & quantity & Percentage distribution (\%) \\
\hline \multicolumn{3}{|l|}{ Industries } \\
\hline Building materials & 27 & 8.8 \\
\hline Chemicals and petrochemicals & 24 & 7.8 \\
\hline Electronics and electrical & 54 & 17.5 \\
\hline Food, beverage and alcohol & 30 & 9.7 \\
\hline Metal, mechanical and engineering & 100 & 32.5 \\
\hline Pharmaceutical and medical & 24 & 7.8 \\
\hline Rubber and plastics & 25 & 8.1 \\
\hline Textiles and apparel & 24 & 7.8 \\
\hline \multicolumn{3}{|l|}{ Age of company } \\
\hline $1-5$ years & 26 & 8.4 \\
\hline $6-10$ years & 76 & 24.7 \\
\hline $11-15$ years & 73 & 23.7 \\
\hline $16-20$ years & 63 & 20.5 \\
\hline $21-30$ years & 44 & 14.3 \\
\hline more than 31 years (including 31 ) & 26 & 8.4 \\
\hline \multicolumn{3}{|l|}{ Number of employees } \\
\hline $100-199$ & 58 & 18.8 \\
\hline $200-499$ & 113 & 36.7 \\
\hline $500-999$ & 67 & 21.8 \\
\hline $1000-4999$ & 52 & 16.9 \\
\hline more than 5000 (including 5000) & 18 & 5.8 \\
\hline \multicolumn{3}{|l|}{ Sales $(\mathrm{RMB})$} \\
\hline 5 million $-<10$ million & 4 & 1.3 \\
\hline 10 million $-<20$ million & 36 & 11.7 \\
\hline 20 million $-<50$ million & 58 & 18.8 \\
\hline 50 million $-<1$ billion & 74 & 24.0 \\
\hline more than 1 billion (including 1 billion) & 136 & 44.2 \\
\hline
\end{tabular}

Table 2. Respondent characteristics

\begin{tabular}{lclc}
\hline Position & \% of respondents & Years in current position & \% of respondents \\
\hline Top manager & $37.6 \%$ & $1-3$ years & $15.6 \%$ \\
Middle manager & $59.8 \%$ & 4-6 years & $34.4 \%$ \\
Other & $2.6 \%$ & 7-12 years & $36.4 \%$ \\
& & More than 12 years & $13.6 \%$ \\
\hline
\end{tabular}


Table 3. Results of exploratory factor analysis

\begin{tabular}{|c|c|c|c|c|c|}
\hline \multirow[b]{2}{*}{ Item } & \multicolumn{5}{|c|}{ Factor loading } \\
\hline & $\begin{array}{l}\text { Customer quality } \\
\text { integration }\end{array}$ & $\begin{array}{l}\text { Supplier quality } \\
\text { integration }\end{array}$ & $\begin{array}{c}\text { Green } \\
\text { purchasing }\end{array}$ & $\begin{array}{l}\text { Customer green } \\
\text { cooperation }\end{array}$ & $\begin{array}{l}\text { Environmental } \\
\text { performance }\end{array}$ \\
\hline SQI01 & 0.199 & 0.798 & 0.169 & 0.139 & 0.123 \\
\hline SQI02 & 0.202 & 0.802 & 0.196 & 0.181 & 0.125 \\
\hline SQI03 & 0.212 & 0.807 & 0.118 & 0.194 & 0.013 \\
\hline SQI04 & 0.198 & 0.827 & 0.130 & 0.118 & 0.101 \\
\hline SQI05 & 0.235 & 0.812 & 0.099 & 0.162 & 0.111 \\
\hline SQI06 & 0.204 & 0.807 & 0.113 & 0.204 & 0.038 \\
\hline SQI07 & 0.245 & 0.815 & 0.175 & 0.164 & 0.069 \\
\hline SQI08 & 0.257 & 0.803 & 0.169 & 0.160 & 0.080 \\
\hline SQI09 & 0.251 & 0.784 & 0.200 & 0.115 & 0.086 \\
\hline CQI01 & 0.794 & 0.219 & 0.103 & 0.204 & 0.060 \\
\hline CQI02 & 0.837 & 0.139 & 0.075 & 0.067 & 0.102 \\
\hline CQI03 & 0.816 & 0.224 & 0.120 & 0.134 & 0.019 \\
\hline CQI04 & 0.815 & 0.273 & 0.141 & 0.169 & 0.011 \\
\hline CQI05 & 0.811 & 0.197 & 0.049 & 0.104 & 0.063 \\
\hline CQI06 & 0.829 & 0.127 & 0.147 & 0.175 & 0.059 \\
\hline CQI07 & 0.837 & 0.179 & 0.077 & 0.133 & 0.056 \\
\hline CQI08 & 0.816 & 0.248 & 0.070 & 0.096 & 0.061 \\
\hline CQI09 & 0.825 & 0.201 & 0.131 & 0.053 & 0.122 \\
\hline CQI10 & 0.832 & 0.195 & 0.155 & 0.123 & 0.039 \\
\hline GP01 & 0.100 & 0.228 & 0.789 & 0.187 & 0.221 \\
\hline GP02 & 0.082 & 0.164 & 0.787 & 0.160 & 0.184 \\
\hline GP03 & 0.182 & 0.224 & 0.812 & 0.175 & 0.158 \\
\hline GP04 & 0.162 & 0.109 & 0.808 & 0.160 & 0.127 \\
\hline GP05 & 0.128 & 0.130 & 0.836 & 0.178 & 0.150 \\
\hline GP06 & 0.090 & 0.201 & 0.839 & 0.193 & 0.121 \\
\hline GP07 & 0.156 & 0.141 & 0.821 & 0.149 & 0.167 \\
\hline CGC01 & 0.239 & 0.235 & 0.177 & 0.761 & 0.196 \\
\hline CGC02 & 0.130 & 0.190 & 0.156 & 0.765 & 0.198 \\
\hline CGC03 & 0.111 & 0.145 & 0.257 & 0.784 & 0.115 \\
\hline CGC04 & 0.162 & 0.160 & 0.122 & 0.839 & 0.083 \\
\hline CGC05 & 0.145 & 0.152 & 0.176 & 0.821 & 0.121 \\
\hline CGC06 & 0.158 & 0.190 & 0.186 & 0.796 & 0.182 \\
\hline CGC07 & 0.146 & 0.200 & 0.153 & 0.778 & 0.145 \\
\hline
\end{tabular}




\begin{tabular}{llllll}
\hline EP01 & 0.092 & 0.079 & 0.233 & 0.118 & $\mathbf{0 . 8 2 1}$ \\
EP02 & 0.070 & 0.085 & 0.175 & 0.182 & $\mathbf{0 . 8 3 9}$ \\
EP03 & 0.036 & 0.153 & 0.212 & 0.202 & $\mathbf{0 . 8 1 9}$ \\
EP04 & 0.069 & 0.079 & 0.147 & 0.220 & $\mathbf{0 . 8 1 3}$ \\
EP05 & 0.123 & 0.109 & 0.172 & 0.120 & $\mathbf{0 . 8 2 5}$ \\
\hline $\begin{array}{l}\text { Eigenvalue } \\
\text { Cumulative }\end{array}$ & 15.382 & 4.912 & 3.310 & 2.791 & 2.336 \\
variance & $19.831 \%$ & $37.664 \%$ & $51.835 \%$ & $65.438 \%$ & $75.608 \%$ \\
explained & & & & & \\
\hline
\end{tabular}

Table 4. Results of confirmatory factor analysis

\begin{tabular}{|c|c|c|c|c|c|c|}
\hline Item & Loading & Std Error & T-value & $\begin{array}{l}\text { Cronbach's } \\
\text { alpha }\end{array}$ & $\begin{array}{l}\text { Composite } \\
\text { reliability }\end{array}$ & $\begin{array}{l}\text { Average } \\
\text { variance } \\
\text { extracted }\end{array}$ \\
\hline Supplie & & & & \multirow{10}{*}{0.959} & \multirow{10}{*}{0.959} & \multirow{10}{*}{0.724} \\
\hline SQI01 & 0.837 & 0.050 & 17.994 & & & \\
\hline SQI02 & 0.862 & 0.048 & 18.872 & & & \\
\hline SQI03 & 0.840 & 0.049 & 18.090 & & & \\
\hline SQI04 & 0.852 & 0.050 & 18.517 & & & \\
\hline SQI05 & 0.851 & 0.049 & 18.490 & & & \\
\hline SQI06 & 0.840 & 0.048 & 18.089 & & & \\
\hline SQI07 & 0.874 & 0.047 & 19.282 & & & \\
\hline SQI08 & 0.864 & 0.048 & 18.924 & & & \\
\hline SQI09 & 0.839 & 0.047 & 18.077 & & & \\
\hline \multicolumn{4}{|c|}{ Customer quality integration } & \multirow{11}{*}{0.962} & \multirow{11}{*}{0.962} & \multirow{11}{*}{0.717} \\
\hline CQI01 & 0.835 & 0.047 & 17.959 & & & \\
\hline CQI02 & 0.829 & 0.049 & 17.737 & & & \\
\hline CQI03 & 0.852 & 0.049 & 18.530 & & & \\
\hline CQI04 & 0.875 & 0.049 & 19.359 & & & \\
\hline CQI05 & 0.818 & 0.049 & 17.393 & & & \\
\hline CQI06 & 0.849 & 0.049 & 18.422 & & & \\
\hline CQI07 & 0.852 & 0.048 & 18.537 & & & \\
\hline CQI08 & 0.846 & 0.050 & 18.305 & & & \\
\hline CQI09 & 0.845 & 0.048 & 18.291 & & & \\
\hline CQI10 & 0.865 & 0.048 & 18.980 & & & \\
\hline \multicolumn{4}{|c|}{ Green purchasing } & \multirow{6}{*}{0.948} & \multirow{6}{*}{0.948} & \multirow{6}{*}{0.724} \\
\hline GP01 & 0.852 & 0.065 & 18.436 & & & \\
\hline GP02 & 0.807 & 0.070 & 16.950 & & & \\
\hline GP03 & 0.882 & 0.070 & 19.533 & & & \\
\hline GP04 & 0.816 & 0.072 & 17.255 & & & \\
\hline GP05 & 0.869 & 0.072 & 19.051 & & & \\
\hline
\end{tabular}




\begin{tabular}{lcccccc}
\hline Item & Loading & Std Error & T-value & $\begin{array}{c}\text { Cronbach's } \\
\text { alpha }\end{array}$ & $\begin{array}{c}\text { Composite } \\
\text { reliability }\end{array}$ & $\begin{array}{c}\text { Average } \\
\text { variance } \\
\text { extracted }\end{array}$ \\
\hline GP06 & 0.879 & 0.072 & 19.419 & & & \\
GP07 & 0.848 & 0.068 & 18.301 & & & \\
\hline Customer green cooperation & & & & & \\
CGC01 & 0.851 & 0.060 & 18.369 & & 0.695 \\
CGC02 & 0.808 & 0.065 & 16.923 & & \\
CGC03 & 0.816 & 0.068 & 17.181 & & \\
CGC04 & 0.845 & 0.065 & 18.167 & 0.940 & 0.941 & \\
CGC05 & 0.847 & 0.069 & 18.216 & & & \\
CGC06 & 0.855 & 0.061 & 18.491 & & & \\
CGC07 & 0.812 & 0.067 & 17.066 & & & \\
\hline Environmental performance & & & & & \\
EP01 & 0.824 & 0.055 & 17.310 & & & \\
EP02 & 0.853 & 0.058 & 18.262 & & \\
EP03 & 0.861 & 0.058 & 18.535 & 0.920 & 0.921 & \\
EP04 & 0.822 & 0.063 & 17.235 & & & \\
EP05 & 0.819 & 0.060 & 17.131 & & & \\
\hline
\end{tabular}

Table 5. Correlation, mean, and standard deviations

\begin{tabular}{lccccrrr}
\hline & 1 & 2 & 3 & 4 & 5 & Mean & SD \\
\hline 1. Supplier quality integration & $\mathbf{0 . 8 5}$ & & & & 5.52 & 0.911 \\
2. Customer quality integration & $0.51^{* *}$ & $\mathbf{0 . 8 5}$ & & & 5.27 & 0.910 \\
3. Green purchasing & $0.44^{* *}$ & $0.34^{* *}$ & $\mathbf{0 . 8 5}$ & & 5.00 & 1.325 \\
4. Customer green cooperation & $0.46^{* *}$ & $0.39^{* *}$ & $0.47^{* *}$ & $\mathbf{0 . 8 3}$ & 5.09 & 1.189 \\
5. Environmental performance & $0.29^{* *}$ & $0.23^{* *}$ & $0.45^{* *}$ & $0.43^{* *}$ & $\mathbf{0 . 8 4}$ & 4.92 & 1.083 \\
\hline
\end{tabular}

Note: Bold italic number in diagonal is the square root of AVE; ${ }^{* *} \mathrm{p}<0.01,{ }^{*} \mathrm{p}<0.05$

Table 6. Bootstrapping results of indirect effects

\begin{tabular}{cccc}
\hline \multirow{2}{*}{ Path } & \multirow{2}{*}{\begin{tabular}{c} 
Indirect \\
\cline { 3 - 4 }
\end{tabular}} & \multicolumn{2}{c}{ Confidence Interval } \\
\cline { 3 - 4 } & effects & Low (2.5\%) & Up (97.5\%) \\
\hline Supplier quality integration -> Environmental performance & 0.205 & 0.131 & 0.297 \\
Customer quality integration -> Environmental performance & 0.108 & 0.048 & 0.187 \\
\hline
\end{tabular}


Table 7. Results of Sobel test

\begin{tabular}{|c|c|c|c|}
\hline Independent variable & Mediator & Dependent variable & $\mathrm{Z}(\mathrm{p})$ \\
\hline Supplier quality integration & \multirow{2}{*}{ Green purchasing } & \multirow{4}{*}{$\begin{array}{c}\text { Environmental } \\
\text { performance }\end{array}$} & $3.86(\mathrm{p}<0.001)$ \\
\hline Customer quality integration & & & $2.27(\mathrm{p}<0.05)$ \\
\hline Supplier quality integration & Customer green & & $3.56(\mathrm{p}<0.001)$ \\
\hline Customer quality integration & cooperation & & $2.73(\mathrm{p}<0.01)$ \\
\hline
\end{tabular}

